\title{
Kinds of Group Communications Performed by The Office of Communication and Information Technology (Diskominfo) to Spread Innovation Development in North Sumatra
}

\author{
Muhammad Alfikri ${ }^{1}$, Syukur Kholil ${ }^{2}$, Suwardi Lubis ${ }^{2}$ \\ ${ }^{I}$ Ph.D Student at State Islamic University of North Sumatra (UINSU), Medan, Indonesia \\ ${ }^{1}$ Lecturer at Ushuluddin Faculty, State Islamic University of North Sumatra (UINSU), Medan, Indonesia \\ ${ }^{2}$ Ph.D Lecturer at State Islamic University of North Sumatra (UINSU), Medan, Indonesia
}

\begin{abstract}
Communication is the act of conveying intended meanings from one entity or group to another through the use of mutually understood signs and semiotic rules. The main steps inherent to all communication are: the forming of communicative motivation or reason, message composition, message encoding, transmission of the encoded message as a sequence of signals using a specific channel or medium, noise sources such as natural forces and in some cases human activity begin influencing the quality of signals propagating from the sender to one or more receivers. Diskominfo Provsu does all its potential dissemination of information through communication regularly. Some forms of communication done by Diskominfo are coffee morning, press conference, empowerment, Public Information Group (KIM) and spreading innovation through coordinated public relations empowerment in Relations Coordinating Board (Bakohumas). Coffee morning is held once a month by inviting community leaders, the central figure in the institutions who are partners in the dissemination of innovation in Diskominfo and religious leaders, as well as all employees at the office of Diskominfo Provsu.
\end{abstract}

Keywords: communication; Diskominfo; coffee morning; press conference

\section{INTRODUCTION}

Communication is something that cannot be separated from human life because as social beings, people are always looking to connect with others. It is done to meet their needs as well as to satisfy curiosity about the surrounding environment. Curiosity eventually encourage people to communicate, gather in groups. Communication is also pushing toward dynamic life. It is parallel with the development of people themselves. The dynamic development of society is not only at one point only, but it also includes various aspects surrounding the life of a community, both from the aspect of social and humanitarian side, as the main actors in society. The technology also plays a very significant role because of the convenience it offers. It also helps to change the lifestyle of the people. Changes in lifestyle of the people is expected to lead the progress and positive impact on people's lives. The technological advances are also encourage the emergence of an innovation in public life. Innovation is an idea, practice, or object that's new to humans or other adoption unit. Innovation as an object has a meaning as a new product or practice that is available and the level of novelty can be distinguished. For example, a new innovation can be an individual or a company, new to the market, or the state and local levels. People are certainly concerned with innovation, because innovation is one of the factors facilitating social change as the core of the development community. As the authors observed in North Sumatra, for example, the provincial government continues to encourage the public to support the provincial government in the success of regional development. North Sumatra is a province that continues to move construction. The aim is to improve and enhance the welfare of the community, as well as his innovation. Therefore, it takes ideas, the application of the latest technology can support development programs and strategies in the development program. Because in the development principle, it is a process of change for the better through the efforts of a planned manner.

In connection with the development of innovation, not all people have good information about it. In fact, some people are indifferent to development undertaken. Due to the good knowledge of the community to innovation development, it is not common communities do resistance, rejection and so on. Therefore, in order to do innovation development accepted by society, it is expected the intervention agencies, which act as a change agent. Institution or person acting as a change agent would be expected from institutions or people who understand or well informed about the development of innovation that will be distributed. It shows that the change agent is expected to bridge between all interest in the development. In the institutional context in North Sumatra, the Office of Communications and Information Technology of North Sumatra Province, Diskominfo 
Provsu, is one of the competent institutions in carrying out the deployment of innovation development in North Sumatra. Diskominfo Provsu is an important element in realizing the organization of the state, primarily in the disclosure to the public. The public has the right to obtain information in accordance with the legislation. The right to get an information is very important because the more open to scrutiny of state administration and it will be more accountable. The right of every person to obtain information can improve the quality of community involvement in making public decision process. Participation or community involvement does not mean much without the guarantee of public disclosure. It is the right of every person to obtain information rapidly, timely, low cost/proportional and simple way. Every public body has a duty to provide access of information relating to the activities of the agency to the public at large. It is mentioned in the Constitution of Indonesia Republic in 1945 Section $28 \mathrm{~F}$, that every person has the right to communicate and obtain information to develop personal and social environment, and the right to seek, obtain, possess and store information by using all kinds of channels available. To provide a guarantee in obtaining information, it is necessary to establish laws governing the public disclosure.

\section{METHODOLOGY}

Communication is the operation, which (re-)produces social systems, it is the central last element (specific operation) for the definition and the retention of society. A change of communicative possibilities by a new medium also changes society. According to Niklas Luhmann, communication is a synthesis of three components: message, information and understanding: communication comes into being, when its understood that an information is imparted. In the social dimension these components are ascribed to at least two abstracted person. Person a (=ego), who understands, and person b (=alter), who imparts. The imparted information can't be identical to the understood information. A process of communication comes into being, if the preceding communication is followed by an succeeding communication. By these communicative connections constitutes meaning to every process of communication, by selecting one certain connection to all possible connections. Communication needs a spreading medium like speech and writing.

Mass Communication refers to medium those appeals to a mass audience by using widely circulating media such as newspapers, magazines, television, and radio to inform, entertain and persuade the large widely dispersed and heterogeneous public. Mass communication is mediated form of communication. This differentiates mass communication from all other forms of communication. According to M. Janowitz in 'The Study of Mass Communication' in International Encyclopedia of Social Sciences, "Mass communication comprises the institutions and techniques by which specialized groups employ technological devices (Radio, TV, Press, films) to disseminate symbolic content to large heterogeneous and widely dispersed audiences."

According to Charles $\mathrm{R}$ Wright, mass communication is a special kind of communication involving distinctive operating conditions, primary among which are nature of the audience, of the communication experience, and of the communicator. Mass communication is directed toward a relatively large, heterogeneous and anonymous audience. Mass communications is characterized as public, rapid and transient. And mass communication is organized communication. One of the finest definitions of mass communication has been given by Denis McQuail in his book Towards Sociology of Mass communication. According to McQuail, "the term mass media indicates the entire systems within which messages are produced, selected, transmitted, received and responded to".

\section{DISCUSSION}

At the institutional context in North Sumatra, the Office of Communications and Information Technology of North Sumatra Province, hereinafter in this study referred to Diskominfo Provsu, is one of the institutions that is competent in carrying out innovation development in North Sumatra. Diskominfo Provsu is an important element in realizing the organization of the state, primarily in the disclosure to the public. The public has the right to obtain information in accordance with the legislation. The right to get information is very important because the more open to scrutiny state administration and it will be more accountable. The right of every person to obtain a relevant information is also can improve the quality of community involvement in making public decision process. Participation or community involvement does not mean much without the guarantee of public information transparency. In order to implement the mandate of the law, Diskominfo Provsu as a co-hosted of an information service is open to the public. As set forth in the documentation of Diskominfo Provsu, it explains that the Communications and Information Agency of North Sumatra Provincial Government has primary responsibility: 1) to prepare materials for the formulation of technical policy in the sphere of communication and information. 2) administering management development, public relation managers, institutional relations and communication services and informatics. 3) reviewing and evaluating communications and public information is an operational of Infokom. The service of Diskominfo touches the public and government interest in performing its function as a servant. It will easier the government in its function as guardian, regulator and driving the advancement of society. To run the optimum services to citizens 
in getting information such as transparent, accountable and clear source of the information, Diskominfo does harness network information system coordinated between institutions. One of the policies is done by forming Public Information Center at the Department of Communications and Information, North Sumatra. In order to support the dissemination of innovation development in North Sumatra, Diskominfo Provsu chooses the communication channel that is relevant to the context of North Sumatra. Theoretically, the selection of communication channels is an effort to support the more rapid innovation to the community. Errors in selecting communications channels often cause ineffective and inefficient information submitted. From observations made on the activities of dissemination of information development undertaken Diskominfo Provsu, the authors noticed that there are three types of communication channels are used, the channels of mass communication, interpersonal communication channel and communication channel group. Mass communication channel is through the use of local mass media, interpersonal communication channels through the utilization of the existence of public figures, and communication channels of the group through the utilization of strategic groups in the community. But from the observations made, the general dissemination of information done by Diskominfo Provsu is very rare. From the interviews conducted, Diskominfo does not promote interpersonal communication due to the limitations of existing development communicators in the agency. In addition, interpersonal communication is more limited in its scope and more complex in its work, so it is more likely to use mass communication and grouped communication. Based on the information presented above, it can be considered some form of communication done by Diskominfo Provsu, namely interpersonal communication channels, but it is frequency slightly. Diskominfo done it through the grouped communication, namely by holding a morning coffee, press conference, in cooperation with public relations at the regency/Bakohumas (Badan Koordinasi Humas) and empowerment of Public Information Group (KIM).

\section{a. Coffee Morning}

Communication is intended to foster good social relations, because humans are social creatures who cannot live alone. So in an institutional context, for example, the communication should be able to give the best to all employees and associated elements. Creating a convenient communication and full of family can drive the organization's reputation in society. In this regard, Diskominfo Provsu designs the communication activities to create an atmosphere through activities

The term of coffee morning is in English, but it is already commonly used in daily terms by the people in Indonesia, especially in offices, institutions and companies., Morning coffee is a social gathering activity to just a light meal and a brief opportunity for government employees or employees of a company to interact. Based on Wikipedia, this term is originally popularized in America and is discovered by the company of Pan America Coffee Bureau in 1952. This activity is initially closely associated with coffee break carried out by 11 members of the British Commonwealth that they have a habit like, morning tea, tea break, or just tea. This term is increasing in other countries, even those that organized an afternoon coffee break, or afternoon tea. The term now extends in the modern world and it is now no longer just a cup of coffee. Coffee morning usually takes about 10-20 minutes done in the morning before running the main tasks. In some institutions, organizations or companies, coffee morning into a formal event is packed with the sources major in it. So, coffee morning is an activity that cannot be separated from the working life of the modern world. It is also done by Diskominfo Provsu, as viewed coffee morning is very important in realizing the unity in the agency. In addition, coffee morning as well as a forum to spread (sharing) information to the public, because in the coffee morning activity it not only among employees of Diskominfo are invited to attend, but it includes other elements of society. In the event, invited speaker in turn, then invited the press and community leaders, and religious leaders. It is closely related to the information submitted by the Head of Diskominfo Provsu. This activity is carried out once a month. Coffee morning not only involves an employee who is inside, but some elements of society that are considered as a strategic partner in broadcasting information in North Sumatra, are also invited. Even in these activities, filled with sources that comes from discipline that studies vary. In the morning coffee activity invited the press and public figures. The aim is to ask for support in order to spread information to the public. Based on the observations made, coffee morning which do Diskominfo just one of the basic elements of internal communications agencies. Coffee morning activities done as a form of communication aims at influencing the level of knowledge, attitudes and behavior of employees and strive to create a family atmosphere among fellow workers, so that the attitude of the employees changed to more productive. Changing in attitude is a socialization process in which a person will react when the stimulus or the stimulus provided by the communicator which can be accepted by the communicant. Theoretically coffee morning is a form of internal communication done to manage the meetings, so as to form a positive communication climate. The atmosphere is relaxed, full of intimacy and togetherness, but preserving the norms as appropriate official meetings which are more formal. Of course by creating a climate of good communication, and maintain a harmonious relationship among employees and also with other partners outside the institution, it can drive the success of the communication made to external agencies 


\section{b. Press Gathering}

One way done by Diskominfo in spreading innovation development in North Sumatra is by press appointment $\mathrm{s}$ to build a good relationship with the press. Almost every week Diskominfo does a press conference in order to spread information to the public. News conference aims to establish good cooperation between Diskominfo with journalists from various mass media. Building a good relationship is very important and the information can be known to the public through the mass media. When observed the condition of real people of North Sumatra, especially for the society living in villages that are hard to reach information, often the novelty of innovation rejected by them. Even the rejection almost generally occurs in the middle of the community who do not understand the emergence of such innovations. Because of the novelty of an innovation, it requires the participation and active involvement of the community, and also the appropriate communication media. The placement of public and media are actively in the process of diffusion of innovation development, placing the public and media in a strong position and powerless, because it can become a regulator for themselves and their surroundings. In these conditions, there is a process of empowerment of the press, because the press empowerment in turn provides room for the dissemination of innovation development done. Novelty idea, product or content of messages conveyed characterizes the diffusion of innovation. The novelty of the ideas is certainly uncommon resistance from the public. As the authors observed in the context of North Sumatra, that the development taking place does not necessarily have the support of the community. For example the construction of highways, construction of airports, railroad construction, development of tourist destinations in several areas, including the relocation of traders and so on, cannot be separated from the public rejection. Things to cause a denial of the other is not, because it is considered something new and contain uncertainty. That is, the uncertainty is afraid not compensable, fear will reduce the amount of its income, fear of damaging the values in society and so on.

In the context of these issues, because they feel it contains something uncertain, or it is considered to be detrimental to ten parties, the press has a significant role. Uncertainty, it can lead to rejection by doing intensive communication, either through dialogical communication or one-way communication through the mass media. Intensive information can encourage adopters to try or experiment to innovation offered. The press conference is made during Diskominfo held important activities, as well as important information needed by the public. The journalists are invited, and then to have them delivered information intended, immediately broadcast to the public. In principle, we look that press conference is very important as the delivery of innovation development efforts undertaken in North Sumatra, so that people know about it. Event press conference is usually welcomed by journalists. Usually they present in accordance with the time specified by Diskominfo. From the information above, it is understood that the press conference is very important because it helps the task of public relations in the dissemination of information to the public. Looking at the information above, it can also be understood that the press conference has the advantage of broadcasting information. Excellence press conference, namely:

\section{Information can be effective}

Press information can be more effective. The information can be delivered more effectively and developing information could be clarified. When viewed from the side of the mass media, then the purpose of the arrival of journalists to the press conference is to search for the required information or news media. Information to be presented may be clarified directly when there is information that one before being disseminated to the public.

\section{Information submitted together}

By having press conference, the information can be done together simultaneously. The news conference condition only once submitted, but it still includes many media, because it involves a wide range of media, both print and electronic. Helpful news conference to disseminate positive information to the public about the activities of the institution so as to improve the image that could support institutions/agencies. This shows clearly the importance of media relations for an organization that is inseparable from the power of the mass media which are not only able to deliver the message to many people.

\section{Dissemination of equal information}

By having press conference, the dissemination of information can be done same and can be carried out simultaneously to the journalists who follow the press conference, so that the information idisplayed in the media is the same. Because the same information submitted, that information can raise awareness. From this strategic, media has the potential to give understanding, raise awareness, change attitudes, opinions, and behaviors as well as goals to be targeted. 


\section{Problem solving of information}

The mazy of information could be resolved because it is already present from various media. In this regard, the institution must demonstrate a trustworthy reputation that the media, should also show its reputation. For example institution always should prepare accurate information on where and whenever requested. This can be done by the agency supplying good information. Based on the analysis conducted by the author of the documentation owned by Diskominfo, it can be affirmed that the measures of Diskominfo, namely: 1) preparation before execution by sending an invitation to the editor minimum of three days before the press conference held. 2) rechecking the invitations have been sent, whether accepted or not by the editors. 3) creating a press release on the topic to be conveyed to the press. 4) appointing and preparing spokeswoman well. The spokesman is from people who know the issues to be discussed. 5) providing in accordance with the consumption of the atmosphere and time.

\section{c. Empowerment of Society Information Group (KIM)}

KIM empowerment is an activity undertaken both provincial government and the level of regency/city in order to strengthen the institutions, so that they can perform their duties and functions independently and creatively in order to manage information and communication. The era of information driven by the development of information and communication technology, has made the world seemed limitless. Human easily and quickly access the information needed. These conditions if it is not matched by the readiness to pick and choose the information available, it could have an impact on the counter-productive in terms of development in all fields. In an effort to answer this challenge the existence of Public Information Group (KIM) as the group grows and develops in the midst of society, is expected to play a role as facilitator to bridge the gap of communication and information that occurs between the government and society (top down) or society and government (bottom up).

\section{d. Public Relation Co-ordination}

Public relation is a very broad field concerning the relationship with the various parties and the existence of public relations at every institution or agency. It is a necessity in order to introduce an activity or event to the community. Its activity or the activity is a means to facilitate the course of the interaction and dissemination of information to the public through various media

\section{Conclusion}

Based on the explanation above, it can be formulated several points. First, in order to provide disclosure of information to the public, Diskominfo Provsu does all its potential dissemination of information through communication regularly. Some forms of communication done by Diskominfo are coffee morning, press conference, empowerment, Public Information Group (KIM) and spreading innovation through coordinated public relations empowerment in Relations Coordinating Board (Bakohumas). Coffee morning is held once a month by inviting community leaders, the central figure in the institutions who are partners in the dissemination of innovation in Diskominfo and religious leaders, as well as all employees at the office of Diskominfo Provsu. Press conference is held at times when there is important information will be conveyed to the public. News conference is carried by inviting journalists from print and electronic media. KIM empowerment is made through discussion, sharing information with KIM in the villages. KIM spearhead the dissemination of innovation to the community. While the group communication via the PR is to empower the PR-public relations in government and private institutions, gathered in one body, namely Bakohumas.

\section{REFERENCES}

[1] Ahmadi, Abu. Psikologi Sosial. Jakarta: Rineka Cipta, 2007.Arifin, Anwar. Strategi Komunikasi: Suatu Pengantar Ringkas. Bandung: Armico, 1984.

[2] Arni, Muhammad. Komunikasi Organisasi. Bandung: PT. Remaja Rosdakarya, 2000.Baron, R. A. dan Byrne D. Psikologi Sosial. Jakarta: Penerbit Erlangga, 2003.

[3] Barker, Cris. Cultural Studies Teori dan Praktik. Yogyakarta: PT. Bentang Pustaka, 2009.Baron, Robert A. dan Don Byrne, Psikologi Sosial. Jakarta. Erlangga, 2003.

[4] Basuki, Heru. Penelitian kualitatif: Untuk Ilmu-Ilmu Kemanusiaan dan Budaya. Jakarta: Universitas Gunadarma, 2006.

[5] Bungin, Burhan. Sosiologi Komunikasi. Jakarta: Kencana, 2009.Cangara, Hafid. Pengantar Ilmu Komunikasi. Jakarta: PT. Raja Grafindo Persada, 2004.

[6] Choiriyati, Wahyuni, dkk. "Kohesivitas Kelompok Dalam Keyakinan Ahmadiyah" dalam Jurnal Thesis Volume VII/ No. 1 Januari - April 2008. Jakarta: FISIP UI, 2008. 
[7] Cohen, Bernard. Revolution in Science. England: Harvard University Press, 1985.Cutlip, Scott M. dan Allen H. Center. Effevtive Public Relations, Merancang dan Melaksanakan Kegiatan Kehumasan Dengan Sukses. Jakarta: Indeks, 2004.

[8] Christopher Harper (2002). The New Mass Media. Houghton \& Miffin, Boston \& New York.Denis Quail (1969). Towards a Sociology of Mass Communications, Collier- MacMillan,

London.

[9] Dennis McQuail (1972). Sociology of Mass Communication: Selected Readings. Penguin rances irncross (1997). The Death of Distance. Harvard Business School Press, Boston.

[10] John Vivian (1999). The Media of Mass Communication. Allyn and Bacon.Joseph Straubhar \& Robert LaRose (2002). Communications Media in the Information

Age. Wadsworth.

[11] Richard Campbell, Christopher R Martin \& Bettina Fabos (2004). Media and Culture: An Introduction to Mass Communication.Bedford/St. Martin.

[12] Departemen Pendidikan Nasional. Kamus Besar Bahasa Indonesia. Jakarta: Balai Pustaka, 2003.

[13] Devito, Joseph A. Komunikasi Antarmanusia, terj. Agus Maulana. Tangerang: Karisma Publishing Group, 2011.

[14] Effendy, Onong Uchjana. Dinamika Komunikasi. Bandung: Remaja Rosdakarya, 2002.

[15] _. Ilmu, Teori dan Filsafat Komunikasi. Bandung: Citra Adtya Bakti, 2000.

[16] _ Hubungan Masyarakat: Studi Komunikologis (Bandung: PT. Remaja Rosdakarya, 1989.

[17] . Ilmu Komunikasi Teori dan Praktek. Bandung: PT. Remaja Rosdakarya, 1984.

[18] Elvinaro dan Soleh Soemirat, Dasar-Dasar Public Relations. Bandung: PT. Remaja Rosdakarya, 2004.

[19] Emery, dkk. Introduction to Mass Communications. New York: Dadd Mead \& Company, 1970.

[20] Fajar, Marhaeni. Ilmu Komunikasi:Teori dan Praktik. Jakarta: Universitas Mercu Buana, 2009.

[21] Goldhaber, Gerald M dan Carl E. Larson. Komunikasi Kelompok; Proses-Proses Diskusi dan Penerapannya, terj. Koedarini Soemiati dan Gary R. Jusuf. Jakarta: UI Press, 1985

[22] Hamalik, Oemar. Pengolahan Sistem Informasi. Bandung: Trigenda Karya, 1993.

[23] Harahap, Edi dan Ahmad Syarwani. Komunikasi Antarpribadi: Perilaku Insani Dalam Organisasi Pendidikan. Jakarta: PT. RajaGrafindo Persada, 2014.

[24] Hasibuan, Malayu. Organisasi dan Motivasi: Dasar Peningkatan dan Produktivitas Kerja. Jakarta: Bumi Aksara, 1996.

[25] Hogg, M. A. dan G. M. Vaughan. Social Psychology. London: Pearson Education, 2002.

[26] Husein, Machnun (Peny). Etika Pembangunan dalam Pemikiran Islam di Indonesia. Jakarta: CV. Rajawali, 1986.

[27] Ibrahim. Problematika Komunikasi Antarbudaya. Pontianak: STAIN Pontianak Press, 2005.

[28] Iriantara, Yosal. Media Relation: Konsep, Pendekatan dan Praktik. Bandung: Remaja Rosdakarya, 2008.

[29] McKenna, C. Powerful Communication Skills, terj. Tim terjemah Elex Media Komputindo. Jakarta: Elex Media Komputindo, 2004.

[30] Kholil, Syukur. Komunikasi Islam. Bandung: Cita Pustaka, 2007.

[31] Khun, Thomas S. Peran Paradigma Dalam Revolusi Sain. Bandung: PT. Remaja Rosdakarya, 1989.

[32] Kriyantono, Rakhmat. Teknik Praktis Riset Komunikasi. Jakarta: Kencana, 2006.

[33] Lauer, Robert H. Perspektif Tentang Perubahan Sosial, terj. Alimandan SU. Jakarta: Bina Aksara, 1989.

[34] Mahmud, Amir. Model Komunikasi Pembangunan Dalam Penyediaan Prasarana Perdesaan di Kawasan Pesisir Utara Jawa Tengah (Studi Kasus Desa Morodemak dan Purwosari Kabupaten Demak). Tesis: Program Studi Magister Teknik Pembangunan Universitas Diponegoro, 2007.

[35] Mardikanto, Totok. Komunikasi Pembangunan. Surakarta: Sebelas Maret University Press, 1987.

[36] McQuail, Denis. Teori Komunikasi Massa. Jakarta, Erlangga, 1984.

[37] Mirra, dkk. Pskilogi Sosial. Pekanbaru: Mujahadah Press, 2013.

[38] Moleong, Lexy. J. Metode Penelitian Kualitatif. Bandung: Remaja Rosdakarya, 2000.

[39] Mulyana, Deddy. Ilmu Komunikasi Suatu Pengantar. Bandung: PT. Remaja Rosdakarya, 2001.

[40] . Komunikasi Efektif: Suatu Pendekatan Lintas Budaya. Bandung: Remaja Rosdakarya, 2005.

[41] Nasution, Zulkarimen. Komunikasi Pembangunan: Pengenalan Teori dan Penerapannya. Jakarta: PT. Raja Grafindo Persada, 2002.

[42] Pakaya, Andrian, dkk. "Pola Penyebaran Informasi Pertanian (Studi Kasus di Desa Botubilotahu Kecamatan Marisa Utara Kabupaten Pohuwato)" dalam Jurnal Penelitian Prodi Ilmu Komunikasi, tahun 2005.

[43] Rachmadi, F. Perbandingan Sistem Pers. Jakarta: Gramedia Pustaka Utama, 1990.

[44] Rakhmat, Jalaluddin. Psikologi Komunikasi. Bandung: PT. Remaja Rosdakarya, 2001.

[45] . Metode Penelitian Komunikasi Dilengkapi Contoh Analisis Statistik. Bandung: Remaja Rosdakarya, 1984 
[46] Rivers, William L. Dkk, Media Massa dan Masyarakat Modern, terj. Haris Munandar. Jakarta: Kencana, 2003.

[47] Rogers, Everett M dan F. Floyid Shoemaker. Communication of Innovations, terj. Abdillah Hanafi. Surabaya: Usaha Nasional, 1981.

[48] Rogers, Everett M. Diffusion of Inovation. London: Colier MacMillan Publishers, 1983.

[49] Salim, Peter. Kamus Besar Bahasa Indonesia Kontemporer. Jakarta: Modern English Press, 1991.

[50] Santoso, Selamet. Dinamika Kelompok. Jakarta: PT. Bumi Aksara, 2004.

[51] Saptono dan Bambang Suteng Sulasmono. Sosiologi. Jakarta: PT. Phibeta Aneka Gama 2007.

[52] Sarwono, Sarlito Wirawan. Psikologi Sosial: Psikologi Kelompok dan Psikologi Terapan. Jakarta: Balai Pustaka, 2002.

[53] Sendjaja, S. Djuarsa. Teori Komunikasi. Jakarta: Universitas Terbuka, 1994.

[54] Shihab, M. Quraish. Membunikan Alquran: Fungsi dan Peran Wahyu dalam Kehidupan Masyarakat. Bandung: Mizan, 1992.

[55] Siswanto. Pengantar Manajemen. Bandung: Bumi Aksara, 2006.

[56] Sobur, Alex. Analisis Teks Media: Suatu Pengantar untuk Analisis Wacana, Analisis Semiotik, dan Analisis Framing. Bandung: PT. Remaja Rosdakarya, 2004.

[57] Soekanto, Soerjono. Sosiologi: Suatu Pengantar. Jakarta: PT Raja Grafindo, 2002.

[58] Sumarto, Hetifah Sj. Inovasi, Partisipasi dan Good Governance. Jakarta: Yayasan Obor Indonesia, 2004.

[59] Sunarto, Kamanto. Sosiologi Kelompok. Jakarta: Pusat Antar Universitas Ilmu-Ilmu Sosial Universitas Indonesia, 1992.

[60] Sunanto, Musyrifah. Sejarah Islam Klasik: Perkembangan Ilmu Pengetahuan Islam. Bogor: Kencana, 2003.

[61] Suprapto, Tommy. Pengantar Teori \& Manajemen Komunikasi. Yogyakarta: Medpress, 2009.

[62] Supratiknya, A. Tinjauan Komunikasi Antar Pribadi. Yogyakarta: Kanisius, 1995.

[63] Susanto, Astrid S. Komunikasi Dalam Teori dan Praktik. Bandung: Bina Cipta, 1977.

[64] Syadily, Hasan. Ensiklopedi Indonesia. Jakarta: Ichtiar Baruvan Hocve.

[65] Taylor, S.E. dkk. Psikologi Sosial. Jakarta: Prenada Group, 2009.

[66] Tangkilisan, Hessel Nogi S. Manajemen Publik. Jakarta: PT Grasindo, 2005.

[67] Tjokrowinoto, Moeljarto. Pembangunan: Dilema dan Tantangan. Yogyakarta: Pustaka Pelajar, 1999.

[68] Tubss, S.L. dan S. Moss. Komunikasi Antarmanusia: Prinsip-Prinsip Dasar, terj. Deddy Mulyana. Bandung: PT. Remaja Rosdakarya, 2000.

[69] Turner. Pengantar Teori Komunikasi. Jakarta: Salemba Humanika, 2008.

[70] Walgito, Bimo. Psikologi Sosial: Suatu Pengantar. Yogyakarta: Andi Offset, 2003.

[71] . Pengantar Psikologi Umum. Yogyakarta: Andi Offset, 2003.

[72] Widjaja, A.W. Komunikasi dan Hubungan Masyarakat. Jakarta: Bumi Aksara, 1997.

[73] Wiryanto. Teori Komunikasi Massa. Jakarta: PT. Gramedia Widia Sarana Indonesia, 2000.Wikepedia

[74] Hasnaini, Imtiaz, "Komunikasi Menurut Pendekatan Islam" dalam Jurnal Komunikasi Audienta, Vol I. No. 1 Januari - Maret 1993. Bandung: PT. Remaja Rosdakarya, 1993.

[75] Prasetyanti, Shinta. "Difusi Inovasi Dalam Konteks Pemberdayaan Masyarakat" dalam Jurnal Acta Diurna Vol. 9, No. 1 tahun 2013.

[76] Tehranian, Majid. "Teori Komunikasi Dalam Perspektif Islam” dalam Jurnal Komunikasi Audienta, Vol I. No. 1 Januari - Maret 1993. Bandung: PT. Remaja Rosdakarya, 1993.

[77] Widodo, Nurdin dan Suradi. "Profil dan Peranan Organisasi Lokal dalam Pembangunan Masyarakat" dalam Jurnal Sosiokosepsia, Volume 16, No. 2, tahun 2011. 